JURNAL WARTA FARMASI
Wttps://poltek-binahusada.e-journal.id/wartafarmasi
Volume 8 | Nomor 2| Oktober | 2019
ISSN: 2089-712X

\title{
Aktivitas Antihiperurisemia Ekstrak Etanol Daun Galing (Cayratia trifolia L. Domin) Pada Mencit BALB/C
}

\section{Antihiperurisemic Activities Of Galing Leaf Ethanol Extract (Cayratia trifolia L. Domin) In BALB / C Mice}

\author{
Muh. Ilyas Yusuf ${ }^{1}$,Nur Saadah Daud ${ }^{2}$, Monika Aqmarina A.H ${ }^{2}$ \\ ${ }^{1}$ Politeknik Bina Husada Kendari, Program Studi Analis Kesehatan Kendari \\ ${ }^{2}$ Politeknik Bina Husada Kendari, Program Studi Farmasi Kendari \\ Jl. Sorumba No. 17 Kendari - Sulawesi Tenggara 93117, Tlp./Fax : 0401-390193 \\ Email : ilyasyusufmuhammad.apt@gmail.com, nursaadah.akfarbinhus@gamil.com
}

\begin{abstract}
ABSTRAK
Salah satu bahan alam yang diduga dapat menurunkan kadar asam urat adalah tumbuhan galing yang mengandung flavanoid. Kemampuan senyawa tersebut dalam menurunkan asam urat yaitu dengan cara menghambat aktivitas xantin oksidase pada basa purin sehingga akan menurunkan produksi asam urat. Tujuan penelitian ini adalah untuk mengetahui aktivitas hiperurisemia dari ekstrak daun galing pada mencit $\mathrm{BALB} / \mathrm{C}$. Pada uji aktivitas antihiperurisemia yang dilakukan pada mencit, diinduksi pottasium oxonat pada dengan dosis $200 \mathrm{mg} / \mathrm{kgBB}$, pada dosis ekstrak daun galing $300 \mathrm{mg} / \mathrm{kg} \mathrm{BB}$, $400 \mathrm{mg} / \mathrm{kg} \mathrm{BB}, 500 \mathrm{mg} / \mathrm{kg} \mathrm{BB}$, kontrol positif allopurinol dan kontrol negatif Na-CMC $0.5 \%$. Hasil uji farmakologi diolah secara statistik menggunakan uji normalitas dan one way ANOVA dan uji LSD (Least Significance Different) dengan program SPSS 20. Hasil penelitian menunjukan pada ekstrak ekstrak daun galing $300 \mathrm{mg} / \mathrm{kg} \mathrm{BB}, 400 \mathrm{mg} / \mathrm{kg} \mathrm{BB}$ dan $500 \mathrm{mg} / \mathrm{kg}$ BB mampu menurunkan kadar asam urat. Secara statistik terdapat pengaruh secara signifikan pada ekstrak daun galing dosis 300 $\mathrm{mg} / \mathrm{kg}$ BB dan dosis $400 \mathrm{mg} / \mathrm{kg}$ BB terhadap penurunan kadar asam urat dengan nilai $\mathrm{P} \quad 0,02<0,05$ artinya terdapat perbedaan efek antihiperurisemia antara kelompok perlakuan.
\end{abstract}

Kata kunci: Antihiperurisemia, ekstrak etanol daun galing, , flavanoid, mencit

\begin{abstract}
One of the natural ingredients that is thought to reduce uric acid levels is a thorny plant which contains flavonoids. The ability of these compounds in reducing uric acid is by inhibiting the activity of xanthine oxidase in the purine base so that it will reduce uric acid production. The purpose of this study was to determine the hyperuricemia activity of the galing leaf extract in BALB / C mice. In the antihyperuricemia activity test conducted on mice, pottasium oxonate was induced at a dose of $200 \mathrm{mg}$ / $\mathrm{kgBW}$, at a dose of galing leaf extract $300 \mathrm{mg} / \mathrm{kgBW}, 400 \mathrm{mg} / \mathrm{kgBW}, 500 \mathrm{mg} / \mathrm{kgBW}$, positive control of allopurinol and negative control of $\mathrm{Na}-\mathrm{CMC} 0.5 \%$. Pharmacological test results were statistically processed using the normality test and one way ANOVA and LSD (Least Significance Different) test with the SPSS 20 program. The results showed that the extract of the galing leaf extract $300 \mathrm{mg} / \mathrm{kg} \mathrm{BW}, 400 \mathrm{mg} / \mathrm{kg} \mathrm{BW}$ and $500 \mathrm{mg} / \mathrm{kg} \mathrm{BW}$ could reduce uric acid levels. Statistically, there was a significant effect on galing leaf extract at a dose of $300 \mathrm{mg} / \mathrm{kg} \mathrm{BW}$ and a dose of $400 \mathrm{mg} /$ $\mathrm{kg} \mathrm{BW}$ on decreasing uric acid levels with a $P$ value of $0.02<0.05$, meaning that there were differences in antihyperuricemia effects between treatment groups.
\end{abstract}


Keywords: Antihyperuricemia, ethanol extract galing leaf, flavanoid, mice

\section{Pendahuluan}

Hiperurisemia (asam urat) adalah keadaan dimana terjadinya peningkatan kadar asam urat diatas normal. Pola makan yang tidak sehat pada masyarakat yang berprotein tinggi, terutama protein hewani yang banyak mengandung purin tinggi, dapat menyebabkan penyakit hiperurisemia (kelebihan asam urat) semakin meningkat (Pribadi dan Ernawati, 2010). Asam urat disebabkan oleh penumpukan kristal di daerah persendian diakibatkan oleh kandungan purin yang dapat meningkatkan kadar asam urat dalam darah antara 0,5$0,75 \mathrm{~g} / \mathrm{ml}$ purin yang dikonsumsi (Asmak, \& Nazulatul 2017).

\section{Hasil Riset Kesehatan Dasar (Riskesdas) sebagaimana yang telah dipublikasikan oleh kementrian kesehatan menunjukan bahwa untuk wilayah Sulawesi Tenggara masih di bawah 7,3\% dari jumlah penderita penyakit sendi di Indonesia dengan sekitar 265 juta jiwa atau 0,12\% dari jumlah penduduk Sulawesi Tenggara menderita penyaki sendi.}

Umumnya untuk mengobati penyakit hiperurisemia digunakan obat-obat sintesis seperti alopurinol. Alopurinol adalah contoh obat yang bekerja untuk menghambat pembentukan asam urat melalui penghambatan aktivitas enzim xantin oksidase (Gilman, dkk., 2012;
Katzung, dkk., 2012; Price and Wilson, 2002). Namun, di samping obat sintetik yang disebutkan di atas, banyak tersedia bahan alam yang secara empiris terbukti berkhasiat dapat menurunkan kadar asam urat darah, salah satunya adalah daun galing.

Tumbuhan galing, pada seluruh bagiannya mengandung berbagai macam golongan senyawa seperti flavonoid, tanin, terfenoid, steroid, minyak lilin kuning (Yusuf, dkk., 2018). Flavonoid dapat bertindak sebagai antioksidan dengan bereaksi dengan radikal bebas yang sangat penting untuk menjaga keseimbangan oksidan dan antioksidan dalam tubuh (Singh S, dkk., 2012; Sowmya S, dkk., 2015).

Berdasarkan penelitian Azmi (2010) dan Mohamed (2005) diduga bahwa senyawa flavanoid yang terkandung pada tumbuhan dapat memberikan efek penurunan kadar asam urat. Kemampuan senyawa tersebut dalam menurunkan asam urat adalah dengan cara menghambat aktivitas xantin oksidase pada basa purin sehingga akan menurunkan produksi asam urat.

\section{Metode Penelitian}

Desain penelitian yang digunakan penelitian ini adalah Pre Test-Post Test With Control Group Design. Rancangan 
Pre Test-Post Test With Control Group Design adalah rancangan penelitian yang membagi menjadi kelompok control dan kelompok perlakuan kemudian pengamatan dilakukan sebelum dan sesudah perlakuan (Sani, 2016).

\section{Alat dan Bahan}

Alat-alat yang digunakan pada penelitian ini adalah alat pengukur kadar asam urat Easy Touch ${ }^{\circledR}$, batang pengaduk, botol kaca, corong, gelas ukur $100 \mathrm{~mL}$, hot plate, spoit oral, mortar dan stamper, sonde, spoit $1 \mathrm{cc}$, spoit $3 \mathrm{cc}$, stopwatch,timbangan analitik, dan wadah maserasi.

Allopurinol, aquadest, ekstrak daun galing, etanol 96\%, kain flannel, dan NaCMC 0,5\%.

\section{Pengambilan dan Pengolahan sampel}

Sampel diambil di JL. H. Latama Bunggulawa, Kota Kendari, Sulawesi Tenggara dengan menggunsksn slst. Disortasi basah dan dicuci sampel dengan air mengalir, kemudian ditiriskan. Dipotong rimpang wualae dan dikeringkan sampel dibawah sinar matahari ditutupi kain berwarna hitam. Disortasi kering sampel kemudian, simplisia kering ditimbang.

\section{Pembuatan ekstrak}

Dimasukkan simplisia daun galing kedalam wadah maserasi. Ditambahkan pelarut etanol 96\% hingga sampel simplisia terendam. Dibiarkan selama 4 hari sambil sesekali diaduk.

\section{Pemekatan Ekstrak}

Ekstrak yang diperoleh lalu dipekatkkan dengan menggunakan alat Rotary Vacum Evaporator hingga di peroleh ekstrak kental.

\section{Cara Kerja}

Cara kerja perlakuan hewan uji yaitu disiapkan alat dan bahan yang akan digunakan.Ditimbang masing-masing hewan uji (mencit). Diambil darah masingmasing mencit melalui vena ekornya untuk mengukur kadar asam urat awal. Di induksikan dengan larutan potassium oxonat $0,2 \mathrm{~mL}$ secara intraperitonial, kemudian dibiarkan selama 1 jam. Kemudian diberikan perlakuan melalui oral pada mencit selama 4 jam, Kelompok I diberikan kontrol Na.CMC 0,5\% kelompok II diberikan suspensi Allopurinol 0,249 mg, kelompok III diberikan dosis 300 $\mathrm{mg} / \mathrm{kgBB}$, kelompok IV diberikan dosis 400 mg/kgBB, Kelompok V diberikan dosis $500 \mathrm{mg} / \mathrm{kgBB}$. Kemudian dilakukan pengukuran masing masing mencit pada jam ke 4 dan dicatat hasilnya.

\section{Hasil Dan Pembahasan}

Penelitian aktivitas antihiperurisemia ekstrak etanol daun galing (Cayratia trifolia 1. domin) pada mencit BALB/C di Laboratorium 
Farmakologi Politeknik Bina Husada Kendari. Pada penelitian ini tumbuhan yang digunakan adalah tumbuhan galing. Diambil di JL. H. Latama Bunggulawa, Kota Kendari, Sulawesi Tenggara. Daun galing dipanen pada pukul 09.00-10.00 pagi sebanyak $2 \mathrm{Kg}$.

Pada pengolahan daun galing menjadi simplisia kering meliputi daun yang telah dikumpulkan kemudian disortasi basah dengan tujuan untuk menghilangkan kotoran-kotoran atau bahan-bahan asing lainya dari sampel.

Setelah disortasi basah kemudian daun galing dicuci dengan air mengalir, pencucian dilakukan untuk menghilangkan tanah dan kotoran lainya yang menempel pada sampel. Pencucian dilakukan dalam waktu sesingkat mungkin karena kemungkinan terdapat beberapa zat yang terkandung dalam simplisia dapat larut dalam air mengalir (Irwan, 2017).

Kemudian dilakukan proses perajangan menggunakan pisau yang berfungsi untuk mempermudah proses pengeringan sampel. Pengeringan dilakukan dibawah sinar matahari langsung yang ditutupi dengan kain hitam sehingga sampel tidak berkontak langsung dengan sinar matahari, hal ini bertujuan agar sampel mencegah terjadinya kerusakan senyawa aktif yang terkandung di dalam sampel (Prasetyo dan Entang Inoriah, 2013). Kemudian dilakukan sortasi kering untuk memisahkan benda-benda asing dan kotoran lain yang masih tertinggal pada sampel timbang 200 gram. Simplisia kering yang diperoleh kemudian diekstraksi menggunakan metode maserasi.

Ekstraksi dengan metode maserasi karena senyawa aktif yang terdapat pada daun galing yaitu flavonoid, dimana flavonoid tidak tahan terhadap pemanasan. Keuntungan metode maserasi menurut Misna dan Khusnul (2016) lebih mudah dalam pengerjaanya dan alat yang digunakan sederhana.

Pelarut yang digunakan adalah etanol 96\%, dimana menurut Misna dan Khusnul (2016) menyebutkan bahwa etanol 96\% bersifat lebih selektif yaitu hanya menarik zat berkhasiat yang dikehendaki, absorbsi baik, kapang dan khamir sulit tumbuh, mudah menguap dan mendapatkan ekstrak kental lebih cepat dibandingkan pelarut etanol $70 \%$. Hasil maserasi daun galing kemudian dievaporasi pada suhu $65^{\circ}$ C selama kurang lebih 5 jam dengan tujuan untuk memperoleh ekstrak kental. Hasil redamen yang didapatkan $1.0 \%$ dengan berat kering simplisia 200 gram.

Pada penelitian ini dilakukan dengan menggunakan 5 kelompok hewan uji dengan jumlah 15 ekor yang terdiri atas 3 
konsentrasi ekstrak yaitu ekstrak dosis 300 $\mathrm{mg} / \mathrm{g}$ BB, Dosis $400 \mathrm{mg} / \mathrm{g}$ BB dan dosis $500 \mathrm{mg} / \mathrm{g} \mathrm{BB}$, Kontrol positif suspensi allopurinol $100 \mathrm{mg}$ dan kontrol negatif $\mathrm{Na}$ CMC 0,5\%. Hewan uji ditimbang dan diukur kadar asam urat awal. Setelah itu masing-masing mencit diinduksi dengan larutan potassium oxonat dosis $200 \mathrm{mg}$ sebanyak $0,2 \mathrm{~mL}$ untuk sekali pakai secara intraperitonial. Penginduksian potassium oxonate merupakan inhibitor urikase dengan memberikan efek hiperurisemia. Dalam kebanyakan mamalia terdapat enzim urikase yang berfungsi mengubah asam urat menjadi alantoin yang lebih mudah larut dalam air (Katzung dkk, 2012). Dengan dihambatnya enzim urikase oleh kalium oksonat, asam urat akan tertumpuk dan tidak tereliminasi dalam bentuk urin (Katrin, dkk. 2009). Setelah penginduksian potassium oxonat kemudian diukur kadar asam urat mencit, selanjutnya diberikan perlakuan pada mencit yaitu pemberian NaCMC 0,5\%, suspensi Allopurinol 0,249 mg, ekstrak etanol daun galing dosis $300 \mathrm{mg} / \mathrm{Kg}$ $\mathrm{BB}$, dosis $400 \mathrm{mg} / \mathrm{Kg} \mathrm{BB}$, dan dosis 500 $\mathrm{mg} / \mathrm{KgBB}$ peroral sebanyak $0,5 \mathrm{~mL} /$ ekor. Kadar asam urat mencit diukur kembali pada jam ke-1, ke-2, ke-3 dan ke-4 untuk melihat penurunan kadar asam urat yang baik. Kadar asam urat mencit pada berbagai perlakuan dapat dilihat pada tabel 2 .

Tabel 2. Kadar Asam Urat Mencit Pada Berbagai Perlakuan

\begin{tabular}{|c|c|c|c|c|c|c|c|}
\hline \multirow[t]{2}{*}{ No. } & \multirow[t]{2}{*}{ Kelompok } & \multirow{2}{*}{$\begin{array}{c}\text { Kadar } \\
\text { asam urat } \\
\text { puasa } \\
\text { awal } \\
(\mathrm{mg} / \mathrm{dL})\end{array}$} & \multirow{2}{*}{$\begin{array}{l}\text { Setelah } \\
\text { pemberian } \\
\text { Pottasium } \\
\text { oxonate }\end{array}$} & \multicolumn{4}{|c|}{$\begin{array}{c}\text { Rata-rata kadar asam urat setelah } \\
\text { pemberian potassium oxonate } \\
(\mathrm{mg} / \mathrm{dL})\end{array}$} \\
\hline & & & & Jam 1 & Jam 2 & Jam 3 & Jam 4 \\
\hline \multirow{4}{*}{1} & \multirow{3}{*}{ Suspensi Na-CMC $1 \%$} & 4 & 5.6 & 5.7 & 6.8 & 6.8 & 5.5 \\
\hline & & 4 & 6.1 & 6.7 & 6.8 & 6.8 & 5.7 \\
\hline & & 4 & 5.1 & 5.6 & 5.9 & 6 & 5.5 \\
\hline & Rata-rata & 4 & 5.6 & 6 & 6.5 & 6.53 & 5.56 \\
\hline \multirow{4}{*}{2} & \multirow{3}{*}{$\begin{array}{l}\text { Suspensi Allopurinol } \\
\text { dosis } 100 \mathrm{mg} / \mathrm{kg} \mathrm{BB}\end{array}$} & 3.1 & 6.8 & 6.5 & 4.9 & 3.4 & 3.7 \\
\hline & & 3.8 & 7.3 & 6.9 & 5 & 3.4 & 3.7 \\
\hline & & 3 & 6.6 & 5.4 & 4.3 & 3.4 & 3.7 \\
\hline & Rata-rata & 3.3 & 6.9 & 6.26 & 4.73 & 3.4 & 3.7 \\
\hline \multirow{4}{*}{3} & Ekstrak Etanol Daun & 4 & 5.7 & 6.4 & 5.4 & 3.4 & 4.9 \\
\hline & Galing dosis $300 \mathrm{mg} / \mathrm{kg}$ & 4 & 6 & 5.4 & 4.8 & 3.4 & 3.7 \\
\hline & BB & 4 & 5 & 5.8 & 4.8 & 3.4 & 4.4 \\
\hline & Rata-rata & 4 & 5.56 & 5.86 & 5 & 3.4 & 4.33 \\
\hline \multirow{4}{*}{4} & Ekstrak Etanol Daun & 3.6 & 5.6 & 6.2 & 6 & 4.4 & 4.7 \\
\hline & Galing dosis $400 \mathrm{mg} / \mathrm{kg}$ & 3.6 & 6.6 & 6.8 & 6.8 & 4.2 & 4.7 \\
\hline & $\mathrm{BB}$ & 3.1 & 6.6 & 5.8 & 5.1 & 5.5 & 4.9 \\
\hline & Rata-rata & 3.43 & 6.26 & 6.26 & 5.96 & 4.7 & 4.76 \\
\hline \multirow{2}{*}{5} & Ekstrak Etanol Daun & 3.1 & 6.2 & 6.1 & 5.3 & 4.4 & 5 \\
\hline & Galing dosis $500 \mathrm{mg} / \mathrm{kg}$ & 3.8 & 6.6 & 6.2 & 3.8 & 4.2 & 5.4 \\
\hline
\end{tabular}

Naskah diterima : 10 September 2019, diterima untuk diterbitkan 20 September 2019, diterbitkan 10 Oktober 2019 


\begin{tabular}{lccllll} 
BB & 3 & 6.7 & 6.4 & 5.8 & 3.8 & 4.2 \\
\hline Rata-rata & 3.3 & 6.5 & 6.23 & 4.96 & 4.13 & 4.86 \\
\hline
\end{tabular}

Pada pengukuran kadar asam urat awal mencit telah mengalami kenaikan kadar asam urat diatas rata-rata kdar asam urat mencit yaitu $0,5-1,4 \mathrm{mg} / \mathrm{dL}$, setelah pemberiam pottasium oxonat mencit mengalami kenaikan kadar asam urat, pada jam ke-1, ke-
2, ke-3, ke-4 kadar asam urat mulai mengalami penurunan kecuali pada suspensi Na-CMC 0,5\%. Grafik dari pengukuran kadar asam urat pada masing-masing perlakuan tertera pada gambar 4.

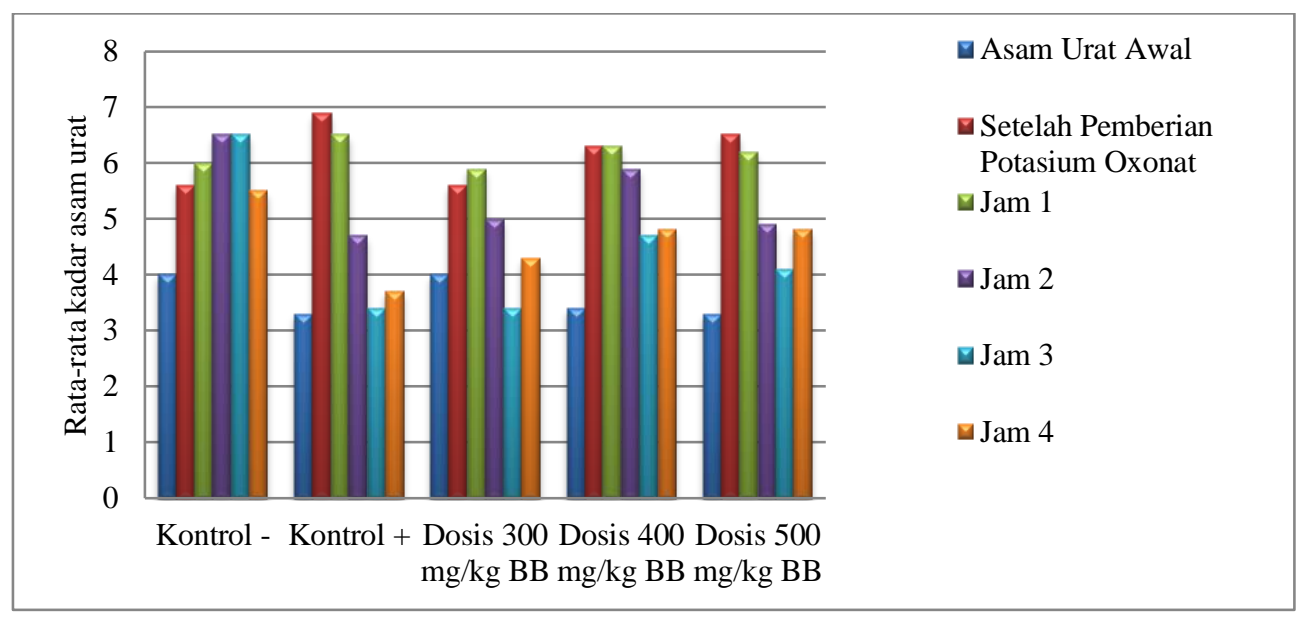

Gambar 4. Grafik kadar asam urat awal, setelah induksi potassium oxonat dan setelah Perlakuan selama 4 jam $(\mathrm{mg} / \mathrm{mL})$.

Berdasarkan gambar 4 terlihat bahwa setelah pemberian potassium oxonat mengalami kenaikan kadar asam urat pada mencit, dan setelah perlakuan selama 6 jam secara peroral kadar asam urat pada mencit yang telah diberi perlakuan dengan ekstak daun galing dengan konsentrasi $300 \mathrm{mg} / \mathrm{g}$ BB, 400mg/g BB, $500 \mathrm{mg} / \mathrm{g} \mathrm{BB}$, suspensi allopurinol 0,249 $\mathrm{mg}$ sebagai kontrol positif dan Na CMC 0,5\% yang digunakan sebagai kontrol negatif.

Penurunan kadar asam urat secara signifikan terjadi pada kelompok perlakuan ekstrak etanol daun galing kosentrasi 300 $\mathrm{mg} / \mathrm{kg}$ BB disebabkan oleh pelarut $76 \%$ dapat menarik zat-zat lain atau zat pengotor yang terkandung didalam ekstrak yang menyebabkan ekstrak etanol daun galing dosis $300 \mathrm{mg} / \mathrm{kgBB}$ lebih baik dari dosis 400 $\mathrm{mg} / \mathrm{kgBB}$ dan $500 \mathrm{mg} / \mathrm{kgBB}$.

Data yang diperoleh kemudian dianalisis statistik menggunakan metode One Way Annova. Analisis statistik yang pertama dilakukan adalah Test of Homogenity of Variances, uji ini menggunakan Lavene test pada kelima kelompok perlakuan. Pada analisis menggunakan lavene test ini, data 
dikatakan homogen jika menunjukkan nilai $\mathrm{P}>0,05$. Hasil analisis lavene test adalah 0,027 yang berarti $\mathrm{P}>0,05$ yang berarti data yang diperoleh tidak homogen. Tetapi jika dilihat dari uji analisis normalitas dengan One-Sample Kolmogorof-Smirnov Test yaitu normal, berarti data yang diperoleh bias menggunakan uji ANOVA.
Uji statistik selanjutnya adalah Anova. Uji ini data dikatakan berbeda secara signifikan apabila nilai $\mathrm{p}<0,05$. Hasil pengujian anova yang diperoleh yaitu p0,02<0,05 artinya terdapat perbedaan efek antihiperurisemia antara kelompok perlakuan. Selanjutnya dilakukan uji LSD yang dapat dilihat pada tabel dibawah ini.

Tabel 3. Beda Nyata Terkecil (BNT)

\begin{tabular}{|c|c|c|c|c|}
\hline LSD & $\begin{array}{l}\text { (I) } \\
\text { perlakuan }\end{array}$ & $\begin{array}{l}(\mathrm{J}) \\
\text { perlakuan }\end{array}$ & $\begin{array}{l}\text { Mean } \\
\text { Difference (I-J) }\end{array}$ & Sig. \\
\hline \multirow{4}{*}{ Jam ke-1 } & \multirow{4}{*}{ kontrol + } & dosis 300 & 0.4 & 0.393 \\
\hline & & dosis 400 & 0 & 1 \\
\hline & & dosis 500 & 0.03333 & 0.942 \\
\hline & & kontrol - & 0.26667 & 0.565 \\
\hline \multirow{4}{*}{ Jam ke-2 } & \multirow{4}{*}{ kontrol + } & dosis 300 & -0.26667 & 0.643 \\
\hline & & dosis 400 & -1.23333 & 0.052 \\
\hline & & dosis 500 & -0.23333 & 0.685 \\
\hline & & kontrol - & $-1.76667^{*}$ & 0.01 \\
\hline \multirow{4}{*}{ Jam ke-3 } & \multirow{4}{*}{ kontrol + } & dosis 300 & 0 & 1 \\
\hline & & dosis 400 & $-1.30000^{*}$ & 0.003 \\
\hline & & dosis 500 & $-.73333^{*}$ & 0.048 \\
\hline & & kontrol - & $-3.13333^{*}$ & 0 \\
\hline \multirow{4}{*}{ Jam ke-4 } & \multirow{4}{*}{ kontrol + } & dosis 300 & -0.63333 & 0.075 \\
\hline & & dosis 400 & $-1.06667^{*}$ & 0.007 \\
\hline & & dosis 500 & $-1.16667^{*}$ & 0.004 \\
\hline & & kontrol - & $-1.86667^{*}$ & 0 \\
\hline
\end{tabular}

$\left(^{*}=\right.$ menujukkan bahwa antara perlakuan yang diuji berbeda secara signifikan dan apabila tidak terdapat * berarti antara perlakuan yang diuji tidak berbeda secara signifikan)

Hasil uji statistik kemudian dilanjutkan pada uji Least Significant Differences (LSD) untuk melihat perbedaan yang nyata secara statistik diantara rata-rata perlakuan. LSD mempertahankan taraf nyata $<0,05$. Pada hasil uji LSD diperoleh nilai signifikansi $\quad 0,000<0,05 \quad$ pada kelompok jam ke-1 tidak ada perbedaan anatara kontrol positif, kontrol negatif, dosis $300 \mathrm{mg} / \mathrm{kg} \mathrm{BB}$, dosis $400 \mathrm{mg} / \mathrm{kg} \mathrm{BB}$ dan dosis 500 $\mathrm{mg} / \mathrm{kgBB}$, tetapi jika dilihat dari data Mean Difference perlakuan yang paling baik adalah dosis $300 \mathrm{mg} / \mathrm{kg}$ BB. Pada kelompok jam ke-2 kontrol negatif dan kontrol positif terjadi perbedaan, sedangkan pada dosis 300 
$\mathrm{mg} / \mathrm{kg} \mathrm{BB}$, dosis $400 \mathrm{mg} / \mathrm{kg} \mathrm{BB}$, dan $500 \mathrm{mg} / \mathrm{kg}$ BB tidak terjadi perbedaan. Pada jam ke-3 dosis $300 \mathrm{mg} / \mathrm{kg}$ BB dan kontrol positif tidak terjadi perbedaan, sedangkan pada kontrol negatif, dosis $400 \mathrm{mg} / \mathrm{kg}$ BB dan dosis $500 \mathrm{mg} / \mathrm{kg}$ BB terjadi perbedaan. Pada jam ke-4 dosis $300 \mathrm{mg} / \mathrm{kg}$ BB dan kontrol positif tidak terjadi perbadaan, sedangkan kontrol negatif, dosis 400 $\mathrm{mg} / \mathrm{kg}$ BB dan dosis $500 \mathrm{mg} / \mathrm{kg}$ BB terjadi perbedaan. Sehingga dapat diketahui bahwa pada penurunan kadar asam urat yang paling baik adalah dosis $300 \mathrm{mg} / \mathrm{kg}$ BB pada jam ke-3 dan ke-4 karena tidak terjadi perbedaan antara konsentrasi 300 $\mathrm{mg} / \mathrm{kg}$ BB dengan kontrol positif. Hal ini diduga karena tumbuhan galing mengandung antioksidan yang kuat dengan $\mathrm{IC}_{50} \quad 61,52 \mathrm{mg} / \mathrm{L}$, kemungkinan besar disebabkan oleh tingginya tingkat flavonoid (Yusuf, dkk. 2018). Kemampuan senyawa tersebut dalam menurunkan asam urat yaitu dengan cara menghambat aktivitas xantin oksidase pada basa purin sehingga akan menurunkan produksi asam urat (Azmi, 2010; Mohamed, 2005).

\section{Kesimpulan}

1. Ekstrak etanol daun galling (Cayratia trifolia L. Domin.) memiliki efek antihiperurisemia pada mencit (Mus musculus L.) yang diinduksi potassium oxonat.

2. Hasil uji Anova menunjukkan bahwa pada jam ke-1, ke-2, ke-3 dan ke-4 dengan dosis $300 \mathrm{mg} / \mathrm{kg} \mathrm{BB}$, dosis 400 $\mathrm{mg} / \mathrm{kg} \quad \mathrm{BB}$, dosis $500 \mathrm{mg} / \mathrm{kg} \quad \mathrm{BB}$ menunjukkan penurunan kadar asam urat, dan dosis yang paling baik digunakan adalah dosis $300 \mathrm{mg} / \mathrm{kg} \mathrm{BB}$.

\section{Ucapan Terima Kasih}

1. Kampus Politeknik Bina Husada Kendari.

2. Dosen-dosen Prodi D-III Farmasi yang telah membantu menyelesaikan artikel penelitian ini.

\section{Daftar Pustaka}

Abdullahi, W., Hamzah, R.U., Jigam, A.A., Yahya, A., Kabiru, A.Y., Muhammad, A., Sakpe, S., Adefolalu, F.S., Isah, M.C. \& Kolo, M.Z. 2012. Inhibitory activity of xanthine oxidase by fractions Crateva adansonii, J. of AcuteDisease, 126-129.

Afif A. Artritis Gout. [internet]. 2008 [disitansi 2014Desember 19]. Tersedia di:http://fajrucmedicine.blogspot.co m /2013/07/apa-itu-artritisgout.html

Akbar Budhi. 2010. Tumbuhan Dengan Kandungan Senyawa Aktif Yang Berpotensi Sebagai Bahan Antifertilitas. Press UIN Jakarta. Hal: 6-7

Asmak, \&Nazulatul. 2017. Hubungan Asupan Bahan Makanan Sumber Purin, Vitamin C, Dan Cairan 
Dengan Kadar Asam Urat Pada Pasien Hiperurisemia Rawat Jalan Di Rumah Sakit Roemani Muhammadiyah Semarang. Universitas Muhammadiyah Semarang.

Azmi, U. 2010). Efek Ekstrak Etanol Daging Buah Mahkota Dewa (Phaleria macrocarpa (Scheff.) Boerl.) Terhadap Penurunan Kadar Asam Urat Pada Mencit Putih Jantan yang Diinduksi Potasium Oxonate. Skripsi. Surakarta: Universitas Muhammadiyah Surkarta.

Erlian. Gout dan Hiperurisemia. [internet]. 2012 [disitansi 2014 Desember 19]. Tersedia di: http://erlianff07.web.unair.ac.id/ph p/ artikel_detail-44983

Febryanti, A. 2016, “Uji Toksisitas Akut Ekstrak Daun dan Batang Galing (Cayratia trifolia L.Domin) Terhadap Larva Udang (Artemia salina Leach)". Karya TulisIlmiah, Amd. Farm, Kendari: Akademi Farmasi Bina Husada, 2016.

Gilman, A.G., Rall, T.W. \& Nies, A. S., Taylor, P. 2012. Goodman and Gilman's the pharmacological basis of therapeutics, 12th Ed., New York. McGraw-Hill.

Hanani, E. 2015. Analisis Fitokimia. ECG. Jakarta. Hal : 86-87

Irwan, Ayu Setiawan, 2017, Uji aktivitas antimikroba Hasil Fraksinasi Ekstrak Rimpang Jeringat (Acorus calanus L.) Terhadap akteri Patogen UIN Alaudin, Makassar.

Kasim, dkk., 2014. Informasi Spesialite Obat Indonesia Volume 49. Jakarta. Hal: 53

Katrin, Soemardji, A. A., Soeganda, A.G., Soediro, I., 2009, The Acute
Toxicity of Isolates From n-hexane and Ethanolic Fraction of Dendrophthoe pentandra (L.) Miq. Which Have Immunostimulatory Activity, Majalah Farmasi Indonesia, 16 (4): 227-231.

Katzung, B.G., Masters, S.B. \& Trevor, A.J. 2012. Basic \& Clinical Pharmacology, 12 Ed., New York: McGraw-Hill.

Kumar D, Gupta J, Kumar S, Arya R, Kumar T, Gupta A. Pharmacognostic Evaluation of Cayratia trifolia (Linn.) Leaf, Asian Pacific J. of Tropical Biomed., 2012, 2;6-10.

Kusumawati, D. 2004. Bersahabat Dengan Hewan Coba. Gadjah Mada Yogyakarta: University Press.

Machfoedz, Ircham. (2007) Metodologi Penelitian: Bidang Kesehatan, Keperawatan, dan Kebidanan. Yogyakarta: Fitramaya.

Mariani, I., \& Bahri, S. (2012). Aktivitas Antihiperurisemia Ekstrak Etanol Herba Suruhan ( Peperomia pellucida ( L .) Kunth ) Pada Mencit Jantan Antihyperuricemic Activity of Ethanol Extract of Suruhan Herb ( Peperomia pellucida ( $L$.) Kunth ) in Male Mice. 1(1), 37-43.

Misna dan Khusnul Diana, "Aktivitas Antibakteri Ekstrak Kulit Bawang Merah (Allium cepa L.) terhadap Bakteri Staphylococcus aureus",Jurnal of Pharmacy Tadulako Farma,Palu, Vol. 2 No. 2, 2016

Misnadiarly. Mengenal Penyakit Artritis. [internet]. 2008 [disitansi 2014 Desember 18]. Tersedia di: http:jurnal.unej.ac.id.index/php/arti cl e/view/2606/2434 
Mazzali, dkk. (2001). Hyperuricemia Induces A Primary Renal Arteriolopathy in Rats By A Blood Pressureindependent Mechanism. Division of Nephrology, Baylor College of Medicine, Houston, Texas. Diakses tanggal 02 Juli 2012.

http://www.ncbi.nlm.nih.gov/pub med/11997315.

Mohamed, N., Wahab, H., Ismail, Z., dan Nessa, Z. (2005). XanthineOxidase Inhibitor. DC: Molecular Basis. http://www.usm.co.id. Tanggal akses 25 juni 2012.

Prasetyo dan Inoriah, E. (2013). Pengelolaan Budidaya Tanaman Obat-obatan (Bahan Simplisia). Bengkulu: Badan Penerbitan Fakultas Pertanian UNIB.

Pribadi, F.W., dan Ernawati, D.A. (2010). Efek Catechin Terhadap Kadar Asam Urat, C-Reaktive Protein(CRP) dan Malondialdehid Darah Tikus Putih (Rattus norvegicus) Hiperurisemia. Mandala of Health. 4(1): 39-46.

Price, S.A. \& Wilson, L. M. 2002, Patophysiology: Clinical concepts of desease processes, 6 Ed., New york.

Rayner Claire. 1990. Bertanyalah Dokter Anda Menjawab. alih bahasa Tetty Y dari judul aslinya Everything Your Doctor would Tell if he had the time. Jakarta. Gaya Favorit Press.

Restiani, A.R., Suhadi, Tuarita, H. 2013. Keanekaragaman Tumbuhan Liani di Hutan Musim Blok Curah Jarak Taman Nasional Baluran. Universitas Negeri Malang. Press, Jawa Timur. aruh Kafein Terhadap Peningkatan kadar Asam Urat Pada Darah Mencit. Tugas Akhir Tidak Diterbitkan. Program S1 Fakultas Malang: Kedokteran. Unibraw.

Sani, $\quad$ K.F., 2016. MetodologiPenelitianFarmasiKomu nitas Dan Eksperimental. Yogyakarta :Depublish

Setyoningsih R. Faktor-faktor Yang Berhubungan Dengan Kejadian Hiperurisemia Pada Pasien Rawat Jalan RSUP Dr. Kariadi Semarang. [internet]. 2009. Tersedia di: http://eprints.undip.ac.id/25234/1/2 3

7_Rini_Setyoningsih_G2C005301. pdf

Simarmata Yettrie B. C., Saragih A, dan Bahri Saiful. Efek Hipourikemia Ekstrak Daun Sidaguri (Sida rhombifolia L) Pada Mencit Jantan. Journal of Pharmaceutics and Pharmacology, 2012 Vol. 1 (1): 2128.

Singh S, Mann R, Sharma SK. Phytochemical Analysis and Pharmacognostical Standardization of Stem of Cayratia trifolia (Linn.) Domin. International Journal of Pharmaceutical Science and Research. 2012;3(11):4503-6.

Sowmya S, Palanisamy CP, Palanirajan A, Balasubramanian V, Prabhakaran $\mathrm{P}$, Deivasigamani $\mathrm{M}$, et al. Preliminary Comparative Analysis Phytochemicals Various Different Parts (Stem, Leaf and Fruit) of Cayratia trifolia (L.), Indo American Journal of Pharmaceutical Research. 2015;5(1):218-23.

Riskana, T. 1999. Peng 
Smith, J.B. dan Soesanto. 1997.

Pemeliharaan, Pembiakan, dan

Penggunaan Hewan Coba di

Daerah Tropis. UI Press. Jakarta.

Yusuf MI, Wahyuni, Susanty S, Ruslan, Fawwaz M. Antioxidant and Antidiabetic Potential of Galing Stem Extract (Cayratia trifolia Domin). Pharmacog J. 2018;10(4):686-9.

Yusuf., Susanti S., Karmila, Indryani PH., 2018. Aktifitas Antibakteri Ekstrak Etanol Daun Cayratia trifolia $L$. Domin. Terhadap Bakteri Escherichia coli. MEDULA Jurna Ilmiah Fakultas Kedokteran Universitas Halu Oleo Medula vol. 6 No.1: 523-529. 